Muttaqin, I., \& Moordiningsih, M. (2019). Dinamika Psikologis Near-death experience. Indigenous: Jurnal Ilmiah Psikologi, 3(2). 79-91. doi: https://doi.org/10.23917/indigenous.v3i2.5655

\title{
Dinamika Psikologis Near-death experience
}

\section{Immamul Muttaqin ${ }^{1}$, Moordiningsih ${ }^{2}$}

Universitas Muhammadiyah Surakarta

Qien.hamed@gmail.com ${ }^{1}$ moordiningsih@ums.ac.id ${ }^{2}$

\begin{abstract}
Some people have experienced Near-death experience. This experience is often caused by severe illness, damage to vital organs due to accidents, or conditions such as being unable to avoid death. The aim of the study is to understand the psychological dynamics of people who have experienced near-death experiences (NDE). Informants in this study were selected by purposive sampling with the number of informants 6 people who met the criteria of the study, who had survived a disease that was at risk of death or had had a severe accident and was convicted of not surviving but survived, aged 17 years and over and willing to become research informants. Analysis In the study using a matrix, descriptive analysis in the form of narration to explain the results of data analysis. Close experience with death includes changes in attitude, activity, and thinking. The researcher concludes that NDE experience begins with the element of cognition as an incident just before the NDE such as often daydreaming, remembering the parents, then there are transcendental elements that are events that occur when the informant experiences NDE experiences such as meeting a white-robed figure, seeing light, seeing himself, meeting relatives who have died and followed by emotional elements in the form of feelings of pleasure, happiness, and having aftereffect sincerely go through life, be able to accept, and reduce fear of death.
\end{abstract}

Keywords: near-death experience, cognitive element, emotion element, transcendental element

Abstraksi.Sebagian orang pernah mengalami pengalaman dekat dengan kematian atau Near-death experience. Pengalaman semacam ini sering kali disebabkan oleh penyakit yang parah, kerusakan organ vital karena kecelakaan, atau keadaan seperti tidak dapat menghidari kematian. Tujuan dari penelitian adalah untuk memahami dinamika psikologis pada orang-orang yang pernah mengalami pengalaman dekat dengan kematian (NDE). Informan pada penelitian ini dipilih secara purposive sampling dengan jumlah informan 6 orang yang memenuhi kriteria penelitian yaitu pernah selamat dalam melawan penyakit yang berisiko kematian atau pernah mengalami kecelakaan parah dan divonis tidak selamat namun bisa selamat, berusia 17 tahun keatas dan bersedia menjadi informan penelitian. Analisis Dalam penelitian menggunakan matriks, analisis deskriptif berbentuk narasi untuk menjelaskan hasil dari analisis data. Pengalaman dekat dengan kematian menyertakan perubahan secara sikap, aktivitas, danpemikiran. Peneliti menyimpulkan bahwa pengalaman NDE diawali dengan elemen kognisi sebagai kejadian sesaat sebelum NDE seperti sering melamun, teringat pada orang tua, kemudian terdapat elemen transendental yaitu kejadian yang terjadi pada saat informan mengalami pengalaman NDE seperti bertemu dengan sesosok berjubah putih, melihat cahaya, melihat dirinya sendiri, bertemu kerabat yang telah meninggal lalu diikuti oleh elemen emosi berupa perasaan senang, bahagia, serta memiliki efek sesudah (aftereffect) ikhlas menjalani kehidupan, mampu menerima, dan berkurangnya rasa takut terhadap kematian.

Kata kunci: kejadian dekat dengan kematian, elemen kognitif, elemen emosi, elemen transendetal 


\section{PENDAHULUAN}

Pengalaman yang sering kali disebut pengalaman dekat dengan kematian atau Neardeath experience (NDE) dialami oleh sebagian individu. Para peneliti menggunakan istilah pengalaman dekat dengan kematian untuk merujuk pada suatu pengalaman orang yang secara klinis mati namun kembali hidup, suatu pengalaman dari orang yang dianggap dekat dengan kematian, dan pengalaman yang membawa pada perubahan personal, baik apakah orang itu telah didekati kematian atau tidak (Greyson, 1998). Pengalaman semacam ini sering kali disebabkan oleh penyakit yang parah, kerusakan organ vital karena kecelakaan, atau keadaan seperti tidak dapat menghindari kematian.

Istilah Near-death experience (NDE) yang berasal dari Bahasa Inggris ini pertama kali diutarakan oleh Moody pada tahun 1975. Definisi pertama Near-death experience menurutnya adalah Suatu pengalaman persepsi secara sadar yang terjadi pada saat mendekati kematian, kemudian dia mendefinisikannya kembali sebagai kejadian dimana seorang individu dapat dengan mudah mati atau dibunuh (dan bahkan dapat sangat dekat untuk dipercayai telah mati) namun bagaimanapun tetap bertahan hidup, dan kembali melanjutkan kehidupan secara fisik (Moody, 1977). Moody kemudian menambahkan definisi ketentuan komponen spiritual yaitu NDE adalah kejadian spiritual mendalam yang terjadi tanpa diundang pada beberapa individu pada titik kematian (Moody dan Perry, 1988).

Lommel (2006) menjelaskan bahwa banyak keadaan yang dideskripsikan pada saat NDE dilaporkan, seperti gagal jantung, trauma setelah kehilangan banyak darah, koma pasca cidera otak traumatis atau intra-cerebral haemorrhage, hampir tenggelam. Kejadian pengalaman dekat dengan kematian dan pengaruhnya pada pasien terlihat mirip diseluruh dunia, antar budaya dan sepanjang waktu. Peristiwa pengalaman dekat dengan kematian secara frekuensi meningkat karena tingkat keselamatan yang naik disebabkan oleh kemajuan pengobatan modern. Pengalaman dekat dengan kematian dapat diartikan sebagai memori dari seluruh kesan pada saat keadaan khusus kesadaran yang telah dilaporkan, termasuk jumlah elemen spesifik seperti pengalaman keluar dari tubuh, perasaan senang, melihat terowongan, cahaya, keluarga yang telah mati, atau kilasan kehidupan (Lommel dkk, 2001).

Lommel dkk (2001) menambahkan NDE adalah memori dari seluruh kesan pada saat keadaan khusus kesadaran yang dilaporkan, termasuk jumlah elemen spesifik seperti pengalaman keluar dari tubuh, perasaan senang, melihat terowongan, cahaya, keluarga yang telah mati, atau kilasan kehidupan. Lebih mendalam lagi Hidayat (2012) menjelaskan bahwa apa yang terjadi puluhan tahun yang lalu dan sudah terlupakan, ketika mengalami mati suri, semuanya menjadi begitu jelas. Jika yang dominan adalah amal kebajikan maka perjalanan ruhnya merasakan kenikmatan dan ketentraman yang luar biasa, yang tidak bisa dijelaskan dengan kata-kata. Sebaliknya, jika yang dominan berupa kejahatan maka ruhnya merasakan kepedihan yang amat sangat.

Peneliti-peneliti NDE, dalam rangka mencoba untuk menghindari bias penemuan penelitian mereka dengan praduga-praduga mereka, mendefinisikan NDE pada hakekatnya sebagai suatu pengalaman secara sadar yang dapat diingat kembali oleh seorang individu setelah mendekati kematian. Sebagian besar individu bereaksi pada trauma mengancam kehidupan dengan ketakutan dan kecemasan intens yang seringkali berlangsung lama setelah ancaman hilang. Sejumlah orang yang berhasil selamat dari trauma tersebut mengalami perkembangan ganguan stress pasca trauma (Post-Traumatic Stress Disorder), yang ditandai dengan kilas balik kehidupan, mimpi buruk, dan tekanan yang signifikan. Lain halnya, beberapa orang yang mengalami trauma tersebut sebagai hal yang penuh kedamaian dan menyenangkan dan disebut dengan "Near-death experience" (Greyson \& Stevenson, 1980;).

NDE telah menarik perhatian beberapa peneliti salah satunya Lommel (2001). Lommel meneliti kontinuitas kesadaran pengalaman 
dekat dengan kematian pada individu yang berhasil selamat dari penyakit gagal jantung. Lommel menjelaskan kesadaran dapat dialami secara independen dari fungsi otak. Hal ini dapat menyebabkan perubahan besar dalam paradigma ilmiah pengobatan, dan bisa memiliki implikasi praktis dalam masalah medis dan etis.

Matamua (2014) membahas tiga karakteristik penting dari NDE yaitu hilangnya rasa takut akan kematian, trauma psikologis, dan kemampuan kesadaran kompleks kemampuan yang mendukung klaim dari penelitian ini. Matamua (2014) menyimpulkan bahwa kurangnya pemahaman dan kesadaran akan psikologi kematian terus meresap pada banyak masyarakat. Kurangnya pemahaman ini masih dilanjutkan oleh etos medis yang melihat kematian sebagai kegagalan, musuh, dan sesuatu yang harus dihindari dengan segala cara.

Para peneliti NDE yang menghubungkan fenomena ini dengan keadaan yang memicu munculnya Near-death experience. Contohnya laporan dengan judul Near-death experiences and the Temporal Lobe yang ditulis oleh Britton dan Bootzin dari University of Arizona pada tahun 2003. Penelitian ini mengungkap fungsi dari temporal lobe pada saat individu mengalami Near-death experience ketika menghadapi kejadian yang mengancam nyawa. Individu yang menjadi subjek eksperimental pada penelitian ini ditemukan memiliki aktivitas temporal lobe epileptiform electroencephalographic yang lebih dari pada subjek kontrol dan juga dilaporkan bahwa mereka secara signifikan memiliki gejala temporal lobe epileptic daripada subjek kontrol. Kelompok NDE juga menunjukan perbedaan dari kelompok kontrol non-traumatis pada pola tidur yang diukur secara objektif yang menunjukan perbedaan psikofisiologis (Britton dan Bootzin, 2003).

Zalika Klemenc-Ketis pada laporannya Life Changes in Patients After Out-of-Hospital Cardiac Arrest: The Effect of Near-death experiences menghubungkan kejadian Near-death experience dengan gejala gagal jantung. Gagal jantung adalah kejadian traumatis yang sering kali mempengaruhi kehidupan pasien dengan berbagai cara. Meskipun kualitas dari kehidupan pasien tersebut, khususnya mereka yang kurang dari 65 tahun, tidak berbeda secara signifikan dari kualitas hidup populasi secara umum, banyak pasien yang menunjukan ganguan neurokognitif dan afektif, terutama ganguan stress pasca trauma (Ketis, 2011).

Berdasarkan penelitian-penelitian di atas dapat disimpulkan bahwa pemicu dari NDE bukan hanya ketika seorang individu mengalami cidera fisik yang menyebabkan individu tersebut mengalami keadaan hampir mati secara fisik, namun juga ketika individu menghadapi keadaan dimana individu tersebut seolah-olah tidak lagi terhindar dari keadaan yang akan membuatnya mati.

Pengalaman NDE menyertakan perubahan ruang, waktu, dan diri; perasaan damai dan euphoria; dan pertemuan dengan cahaya terang, tokoh religi, atau kerabat yang telah meninggal (Greyson \& Stevenson, 1980). NDE biasanya menyertakan batasan-batasan ruang, waktu, dan persepsi yang dilampaui, dan menyertakan kombinasi elemen kognitif, emosional, dan transendental.

Sering kali dari laporan individu berbagai elemen-elemen timbul ketika mereka menghadapi NDE. Hal ini sesuai dengan penelitian yang dilakukan oleh Matamua (2014) yaitu banyak elemen-elemen NDE telah dilaporkan pada semua kultur, meskipun pengalaman kultur membentuk interpretasi dari laporan-laporan tersebut. Kesamaan antar kultur dalam fenomenologi NDE menyatakan komponen kematian kemungkinan mirip secara lintas budaya.

Elemen-elemen dari NDE dari Greyson (2000) dan Schroter-Kunhardt (1993) menjabarkan ada tiga elemen, yaitu:

1. Elemen kognitif menyertakan pemfungsian yang luar biasa seperti perubahan persepsi waktu, kewaspadaan yang meningkat, pembangkitan ingatan yang cepat dalam bentuk kilas balik kehidupan, dan kemampuan kesadaran disamping perasaan terpisah dari badan.

2. Elemen emosional menyertakan intens akan rasa senang, bahagia, damai dan cinta tanpa syarat. 
3. Elemen transendental menyertakan perasaan ditarik ke cahaya yang sangat terang, melihat orang yang telah meninggal, berkomunikasi dengan mahluk bercahaya, dan kesatuan kosmik (Greyson, 2000; Schroter-Kunhardt, 1993).

\section{Pengalaman NDE menyertakan} perubahan ruang, waktu, dan diri; perasaan damai dan euphoria; dan pertemuan dengan cahaya terang, tokoh religi, atau kerabat yang telah meninggal (Greyson \& Stevenson, 1980). NDE biasanya menyertakan batasan-batasan ruang, waktu, persepsi yang dilampaui, serta menyertakan elemen kognitif, emosional, dan transendental. Elemen kognitif menyertakan pemfungsian yang luar biasa seperti perubahan persepsi waktu, kewaspadaan yang meningkat, pembangkitan ingatan yang cepat dalam bentuk kilas balik kehidupan, dan kemampuan kesadaran disamping perasaan terpisah dari badan. Elemen emosional menyertakan intens akan rasa senang, bahagia, damai, dan cinta tanpa syarat. Elemen transendental menyertakan perasaan ditarik ke cahaya yang sangat terang, melihat orang yang telah meninggal, berkomunikasi dengan mahluk bercahaya, dan kesatuan kosmik (Greyson, 2000; Schroter-Kunhardt, 1993).

Menurut dua penelitian di atas, dapat disimpulkan bahwa elemen-elemen Near-death experience yang telah dilaporkan memiliki kemiripan-kemiripan bahkan pada lintas budaya yang berbeda. Elemen-elemen tersebut terdiri dari elemen kognitif, elemen emosional, serta elemen transendental.

Pengalaman Near-death experience sering kali dihubungkan dengan perubahan positif yang berlangsung lama, khususnya, penurunan ketakutan dan kecemasan dan meningkatnya pengaruh positif (Greyson \& Stevenson, 1980; Groth-Marnat \& Summers, 1998). Studi dari Zalika Klemenc-Ketis (2011) menunjukan bahwa subjek tidak menunjukan perubahan kehidupan ektensif namun disisi lain, kehadiran dari Near-death experience adalah signifikan sehubungan dengan kekuatan dari perubahan pada beberapa area kehidupan. Pada khususnya, tiga karaktiristik NDE - hilangnya rasa takut akan kematian, gejala sisa psikologis, dan kemampuan kesadaran kompleks - dapat memberikan wawasan dalam fenomenologi psikologis dari tahap awal kematian (Matamua, 2014)

Beberapa peneliti Near-death experience juga menyetujui hal serupa yang diutarakan oleh Ketis (2011). Disamping perubahan dan potensi traumatis Near-death experience yang dapat dimiliki, sejumlah gejala sisa dilaporkan oleh mereka yang memiliki NDE (Atwater, 2008). Noyes dalam penelitiannya berpendapat bahwa pengaruh NDE tidak serta merta langsung bisa dirasakan oleh individu yang mengalami NDE. Mungkin memerlukan beberapa waktu sebelum seorang individu mampu untuk mengintegrasi NDE ke dalam kehidupan mereka pada cara yang dapat diterima, dan dampaknya setelah kejadian dapat tidak muncul selama berbulanbulan setelah NDE (Noyes dkk., 2009).

Ketis (2011) menyebutkan "Apapun penyebab Near-death experience, pasien yang mengalami kejadian-kejadian ini berhak mendapatkan perhatian terutama dari ahli kesehatan yang menghadapi pasien semacam ini pada kesehariannya”. Masih dari Ketis (2011) disebutkan bahwa perubahan kehidupan setelah NDE terjadi dalam empat segment: kehidupan sosial (ekpresi perasaan dan empati yang lebih, pemahaman dan kewaspadaan akan kebutuhan orang lain yang lebih), hubungan terhadap religi dan spiritualitas (pemahaman arti kehidupan, minat yang lebih akan religi, toleransi yang lebih akan agama lain), hubungan terhadap kematian (tidak lagi takut akan kematian, percaya akan kehidupan akhirat, penerimaan kematian dan sekarat), dan perubahan yang lain (pemahaman kehidupannya sendiri, materialisme yang berkurang).

Berdasarkan teori-teori tersebut dapat disimpulkan bahwa Near-death experience sering kali berhubungan dengan perubahanperubahan positif yang berlangsung lama walaupun tidak serta merta langsung bisa dirasakan oleh orang yang mengalami NDE. Perubahan-perubahan tersebut secara umum berhubungan dengan hubungan sosial, 
hubungan religi, hubungan persepsi akan kematian dan perubahan-perubahan lainnya.

Berdasarkan paparan di atas maka penelitan

ini bertujuan untuk mengetahui dinamika psikologis dari Near-death experience.

\section{METODE PENELITIAN}

Penelitian ini menggunakan metode kualitatif studi kasus. Informan pada penelitian ini penelitian dipilih dengan purposive sampling. Kriteria informan dalam penelitian ini antara lain:

1. Orang yang pernah mengalami Near-death experience, yaitu orang-orang yang pernah survive dalam melawan penyakit yang berisiko kematian atau pernah mengalami kecelakaan parah dan divonis tidak selamat namun bisa selamat dan sembuh total.

2. Berusia 17 tahun keatas.

3. Bersedia menjadi informan penelitian.

\section{HASIL DAN PEMBAHASAN}

Peneliti mendapatkan enam Subyek dengan identitas berikut ini

Makna Near-death experience adalah sebagai sebuah fase atau kejadian yang menyebabkan terjadinya perubahan secara sikap, aktivitas, dan pemikiran dalam kehidupan. Peneliti tidak menemukan hubungan antara pemaknaan NDE dengan usia ketika kejadian, jenis kelamin, maupun jenis NDE yang dialami informan. Seluruh informan menyatakan kejadian NDE sebagai kejadian yang telah merubah kehidupan dari pelakunya. Pernyataan ini sesuai dengan pengalaman NDE seringkali dihubungkan dengan perubahan positif yang berlangsung lama, khususnya, penurunan ketakutan dan kecemasan dan meningkatnya pengaruh positif (Greyson \& Stevenson, 1980; Groth-Marnat \& Summers, 1998). Greyson menyertakan perubahan diri secara perilaku, cara berpikir dan aktivitas kehidupan dari pelaku NDE kejadian sebagai salah satu ciri-ciri dari kejadiannya.

Selanjutnya, dalam NDE terdapat elemenelemen yang menyertai baik sebelum, sesudah dan saat kejadian NDE tersebut terjadi. Elemen- elemen tersebut yaitu kognitif, emosi, dan transendetal. menurut Greyson (2000, dikutip dalamSchroter-Kunhardt, 1993) elemen kognitif menyertakan pemfungsian yang luar biasa seperti perubahan persepsi waktu, kewaspadaan yang meningkat, pembangkitan ingatan yang cepat dalam bentuk kilas balik kehidupan, dan kemampuan kesadaran disamping perasaan terpisah dari badan. Penjelasan ini sesuai dengan hasil penelitian di mana informan menunjukan perilaku yang berbeda terhadap diri sendiri dan masyarakat. Informan menunjukan bahwa informan lebih waspada akan keadaan fisik dan mental informan. Elemen kognisi yang ditemukan pada penelitian ini berhubungan dengan kejadian sebelum pengalaman NDE terjadi. Kejadian tersebut dimaknai sebagai tanda-tanda akan datangnya peristiwa yang akan berpengaruh besar pada kehidupan. Elemen kognisi ini terlihat menonjol pada informan yang mengalami pengalaman NDE merasa dekat dengan kematian.

Elemen yang selanjutnya adalah elemen transendental. Greyson \& Stevenson (1980) menyatakan mengenai deskripsi NDE sebagai berikut; pengalaman NDE menyertakan perubahan ruang, waktu, dan diri; perasaan damai dan euphoria; dan pertemuan dengan cahaya terang, tokoh religi, atau kerabat yang telah meninggal (Greyson \& Stevenson, 1980). Informan dalam penelitian ini mengalami NDE berbeda-beda pengalamannya. Elemen transendental terjadi ketika informan mengalami kejadian NDE yang menyertakan kejadian simbolis yang maknanya berbedabeda sesuai dengan kejadian dan interpretasi informan. Salah satu informan menceritakan kejadian NDE nya disertai dengan menyaksikan dirinya berada di suatu padang pasir yang sangat luas dan matahari yang berada sangat dekat. Sedangkan informan lain menceritakan saat kejadian NDE ia menyaksikan sendiri kejadian kecelakaan yang dialaminya lalu kemudian merasakan dirinya berada di suatu alam lain dengan padang rumput yang luas. Salah satu ciri dari NDE adalah bertemu dengan sesosok mahluk, tokoh religi, atau kerabat yang telah meninggal. Beberapa informan menunjukan ciri 
yang sama pada kejadian NDE nya.

"Wah saya sepertinya waktu dibonceng itu ngantuk, saya tidur, trus saya sadar, trus saya, nganu temen saya e kok rung teko-teko, kurang sak enggokan Git, adoh men. Tapi iki, iki menurut aku ya, daerah sebelah kiri saya itu seperti padang rumput yang luas." (W-5: 308-312)

Elemen yang selanjutnya adalah elemen emosi. Elemen emosional menyertakan intens akan rasa senang, bahagia, damai, dan cinta tanpa syarat (Greyson, 2000; Schroter-Kunhardt, 1993). Peneliti menyimpulkan bahwa elemen ini merupakan efek sesudah kejadian NDE. Pada penelitian ini informan menunjukan bahwa kejadian NDE informan menyertakan perasaan lega dan perasaan lebih bisa menerima keadaan hidupnya. Informan juga menyatakan kejadian NDE telah membawa informan kepada keadaan dimana informan merasa lebih damai dalam menjalani kehidupan informan. Peneliti tidak menemukan ada perbedaan yang signifikan antara usia kejadian, jenis kelamin, jenis kejadian NDE yang dialami informan.

Informan W menunjukan bahwa informan merasakan perubahan dalam bersikap, aktivitas, dan cara berpikir dalam kehidupan informan. Informan merasa lebih tenang, lebih bersyukur dan lebih mawas diri dalam menjalanikehidupan. Pasca kejadian NDE lebih berpikir kearah yang positif.

"Ya bersyukur jadi saya masih diberikan kesempatan untuk berbuat." (W-2: 150151)

Lebih menerima, itu perubahan drastis nggak sih? Ya lumayanlah ya, lebih menerima, lebih nggak tersinggungan, nah lupus tuh bisa tersinggungan banget lo lupus tu. (W-1: 220225)

Menikmati ya gimana ya, ya menerima apa adanya gitu tho, kita misalnya punya sepeda motor ya kita manfaatkan sepeda motor untuk main, kemana, yang penting kan kita bahagia simple nya itu. (W-4: 235-237)

Hal ini sejalan dengan pernyataan dari Matamua (2014). Pada khususnya, tiga karakteristik NDE - hilangnya rasa takut akan kematian, gejala sisa psikologis, dan kemampuan kesadaran kompleks - dapat memberikan wawasan dalam fenomenologi psikologis dari tahap awal kematian.

NDE adalah kejadian yang disertai elemen kogntif, elemen emosional, dan elemen transcendental di mana seseorang merasa mendekati kematian atau tidak dapat terhindar lagi dengan kematian namun karena suatu hal berhasil bertahan hidup lalu mengalami perubahan-perubahan dalam kehidupannya. Kejadian ini pada umumnya diawali dengan elemen kognisi sebagai penanda sebelum NDE terjadi berupa kejadian yang tidak biasa terjadi pada orang yang mengalaminya, kemudian terdapat elemen transendental yaitu kejadian simbolis seperti berada di suatu tempat, melihat cahaya, bertemu dengan keluarga yang telah meninggal, yang memiliki makna tertentu dan terjadi pada saat informan mengalami pengalaman NDE diikuti oleh elemen emosi yang merupakan efek sesudah (aftereffect) dari kejadian NDE berupa perubahan pada sikap diri dan cara pandang terhadap kehidupan. Perbedaan yang paling besar terlihat adalah pada penyebab kejadian NDE yang dialami yaitu merasa dekat dengan kematian seperti kecelakaan atau kerusakan organ vital dan terjangkit penyakit parah. Pada informan yang terjangkit parah tidak menunjukan informasi yang signifikan terhadap elemen kognisi dan transendental. Sedangkan satu informan tidak dapat memberikan informasi mengenai elemen kognisi dan transendental karena mengalami hilang ingatan.

\section{Makna NDE pada orang yang mengalaminya}

Near-death experience sebagai kejadian yang membawa perubahan pada diri informan. Sebagai contoh informan SR membagi pengalamannya menjalani kehidupan dengan penyakit mematikannya dengan menulis buku. Informan B menyatakan dirinya menjadi lebih dibutuhkan oleh masyarakat sekitar. Informan B memiliki panti asuhan yang dikelolanya 
secara mandiri. Informan $S$ menyatakan bahwa semua kejadian itu adalah resiko pekerjaannya yang harus dijalani dengan ikhlas. Informan RW setelah kejadian NDE menyatakan bahwa dirinya ingin lebih menghabiskan waktunya bersama dengan orang terdekatnya.

"Oh malah justru saya, dari pengalaman itu saya ini, ehm apa ya? Dengan, dengan jiwa saya ini dibutuhkan orang lain." (W-2: 8184)

Maka NDE adalah sebagai sebuah fase atau kejadian yang menyebabkan seseorang merasa dekat dengan kematian kemudian terjadi perubahan secara sikap, aktivitas, dan pemikiran dan menjadikan seseorang merasa lebih berguna dalam kehidupan orang yang mengalaminya. Peneliti tidak menemukan perbedaan jenis kelamin, penyebab kejadian NDE, dan usia kejadian tidak memberikan pengaruh yang signifikan terhadap pemaknaan informan mengenai kejadian NDE yang dialaminya.

2. Elemen psikologis yang dialami oleh orang yang mengalami NDE

a. Elemen Kognisi

Terdapat elemen kognitif yaitu pikiran yang muncul menyertai kejadian NDE. Pada penelitian ini dua informan menyatakan hal sama ketika mengalami kejadian NDE yaitu memikirkan orang yang paling berpengaruh dalam kehidupan informan yaitu ibu informan.

"Ya memikirkan ibu saya, yang waktu itu sakit, opname di Surabaya." (W-5: 63-64) "Listriknya didepan mata, clap, gitu kan, langsung inget wajah ibu saya. Nggak sadar tiba-tiba saya ada di itu, seperti gurun pasir kan." (W-6: 90-94).

Informan lain menyatakan dirinya mengalami rasa sakit yang luar biasa setelah kejadian NDE.

"Malah nggak ada sama sekali pikiran apaapa, tiba-tiba kejang, ya udah, kejang kok kayaknya semakin, semakin kenceng semakin kenceng, lalu tubuhnya seperti lebur dah itu." (W-4: 83-86)

Informan $S$ yang mengaku bertemu dengan ular di jalan sebelum pergi bekerja yang mana menurut budaya setempat itu merupakan suatu pertanda buruk. Informan SSBW menyatakan sebelum kejadian NDE informan selalu teringat dengan ibu informan yang sedang menjalani perawatan di rumah sakit. Pada kejadian selanjutnya informan SSBW menyatakan bahwa informan merasa bertemu dengan ibu informan di padang rumput yang luas. Informan RW menyatakan bahwa sebelum kejadian salah satu teman informan tiba-tiba menawari informan sebuah pekerjaan. Berdasarkan makna dari jawaban tersebut dapat disimpulkan bahwa elemen kognisi berhubungan dengan tandatanda sebelum kejadian NDE terjadi.

Tanda-tanda tersebut merupakan kejadian yang tidakbiasa terjadipadakehidupan informan. Peneliti tidak menemukan perbedaan yang signifikan antara elemen kognisi dengan jenis NDE dan usia saat kejadian namun informan B mengaku tidak terlalu bisa mengingat kejadiankejadian sebelum NDE terjadi karena usianya yang masih kecil. Informan SR dan RAN tidak menjawab pertanyaan mengenai elemen kognisi dengan tanda-tanda sebelum mengalami NDE. Informan SR dan informan RAN mengalami NDE yang disebabkan oleh penyakit parah yang tidak dapat disembuhkan.

\section{b. Elemen Transendetal}

Informan SSBW saat kejadian NDE ia melihat suatu kecelakaan di jalan sedangkan sebenarnya dialah yang mengalami kecelakaan tersebut. Informan merasa berada di alam lain yaitu berupa suatu padang rumput yang luas.

"Wah saya sepertinya waktu dibonceng itu ngantuk, saya tidur, trus saya sadar, trus saya, nganu temen saya e kok rung teko-teko, kurang sak enggokan Git, adoh men. Tapi $i k i$, iki menurut aku ya, daerah sebelah kiri saya itu seperti padang rumput yang luas. " (W-5: 308-312)

Salah satu ciri dari NDE adalah bertemu 
dengan sesosok mahluk, tokoh religi, atau kerabat yang telah meninggal. Beberapa informan menunjukan ciri yang sama pada kejadian NDE nya.

"Aku ketemu sama orang-orang yang ada disekitar aku tapi udah meninggal gitu. Dan aku ikut mereka atau yang paling parah tu akhir-akbir ini tu semenjak aku di Cirebon tu banyak yang mimpiin aku meninggal," (W-1: 693-705)

"Iya, saya di ruangan yang gelap itu, di dalam goa yang gelap, nah orangnya itu di depan pintu goanya itu. Nah diluar goa itu terang banget mas, jadi orang itu di tengah-tengah cahaya dari luar itu. Didepan pintunya itu, sambil bilang, gimana itu, udah dijalani aja itu sudah jadi takdirmu. Iklasin aja, yang penting berbuat lebih lagi gitu mas." (W-6: 478-484)

Peneliti menemukan bahwa elemen transendental berhubungan dengan kejadian yang terjadi pada saat informan mengalami NDE. Kejadian-kejadian tersebut memiliki makna yang berbeda-beda sesuai dengan interpretasi informan yang mengalaminya. Informan RW sebagai contoh memaknai kejadian dimana informan merasa berada di sebuah padang pasir yang sangat luas dengan pembatas batu besar yang menjulang keatas dimana informan berusaha untuk mencari jalan keluar sebagai bentuk firasat bahwa informan harus meninggalkan kebiasan-kebiasan buruk yang sering dilakukan informan seperti minum minuman keras dan meninggalkan ibadah. Informan RW juga mengaku bertemu dengan sesosok mahluk di mulut goa. Informan RW menyimbolkan kejadian ini sebagai pedoman untuk bersikap pasrah dan tetap menjalani kehidupannya atas kejadian NDE yang membuatnya cacat secara fisik.

Informan SSBW memaknai elemen transedental yang terjadi yaitu berada di suatu padang rumput yang luas dengan kendaraan berlalu lalang sebagai perpindahan ruh yang meninggal dan ruh yang akan dilahirkan.
Informan menyatakan bahwa sosok ibu informan yang membawa kembali ruh informan ke dunia. Informan B menyatakan kejadian elemen transendental dengan kejadian bermain di sebuah taman bersama dengan teman masa kecilnya. Namun informan tidak bisa menjelaskan makna kejadian tersebut karena informan tidak terlalu mengingat kejadian tersebut yang telah terjadi ketika informan berusia masih sangat muda yaitu ketika informan berusia tujuh tahun.

Peneliti menemukan perbedaan yang signifikan antara penyebab NDE dan elemen transendental yang menyertai informan. Informan dengan penyebab NDE penyakit parah cenderung tidak banyak mengalami kejadian-kejadian tidak wajar. Sedangkan informan dengan penyebab NDE keadaan merasa tidak terhindar dari kematian mengalami kejadian tidak wajar dengan makna tertentu. Namun demikian informan $S$ menyatakan tidak dapat mengingat kejadian elemen transendental karena mengalami hilang ingatan dan informan B menyatakan tidak terlalu ingat dengan kejadian elemen transendental karena kejadian tersebut sudah terjadi sangat lama.

\section{c. Elemen Emosi}

Elemen yang menyertai kejadian NDE selanjutnya adalah elemen emosi. Salah satu informan menyatakan dirinya lebih bersyukur dengan apa yang telah dialami oleh informan karena informan merasa kesabaran dan keiklasan dalam menjalani hidupnya bertambah.

Saya bersyukurnya saya diberikan kesabaran, saya diberikan keiklasan, itu yang saya rasakan walaupun saya nggak punya apaapa. Walaupun dengan hutang-hutang saya hanya bisa merawat dia dengan sabar, merawat mereka dengan ikhlas, ya sepenuhnya dengan...(W-2: 209-214)

Informan lain menyatakan perasaan yang lebih tenang dan lebih bahagia setelah kejadian NDE. Hal ini disebabkan karena ia lebih bisa menerima keadaan hidupnya.

Kalau sekarang sih malah udah bisa menerima 
ya, menerima justru kita menjalaninya enak. Hidup ini enak. (W-4: 177-178)

Lebih tenang, lebih tenang sih lebih tepatnya. Lebih tenang, dulu panik, marah dan sedih dan bla, bla, bla tapi sekarang... Sekarang sedih masih ada tapi, lebih tenang aja, lebih oh ya udah. Lebih nerima! (W-1: 595-599)

Peneliti dengan menggunakan makna lampiran matrik pada elemen emosi sebagai dasar menemukan bahwa perubahan setelah kejadian Near-death experience yang terjadi pada informan adalah perubahan dalam diri informan dan cara pandang terhadap kehidupan yang berbeda yaitu merasa lebih bersyukur, lebih lega dan lebih dapat menerima serta perasaan damai dan euphoria. Berdasarkan matrik tersebut, peneliti menyimpulkan bahwa elemen ini memiliki efek sesudah (after effect) dari Neardeath experience dimana orang pernah mengalami NDE dihubungkan dengan perubahan diri dan cara pandang kehidupan yang berbeda. Peneliti tidak menemukan perbedaan yang signifikan bahwa perbedaan usia, usia kejadian NDE, jenis kelamin, atau penyebab NDE terhadap jawaban informan mengenai elemen emosi.

3. Perubahan yang terjadi pada orang dengan pengalaman NDE sebelum dan sesudah

Ketika diberi pertanyaan mengenai perbedaan sebelum dan pasca kejadian NDE informan menunjukan bahwa informan mengatakan bahwa informan merasakan pemikiran kearah yang lebih positif.

Ya bersyukur jadi saya masih diberikan kesempatan untuk berbuat. (W-2: 150-151) Lebih menerima, itu perubahan drastis nggak sih? Ya lumayanlah ya, lebih menerima, lebih nggak tersinggungan, nah lupus tuh bisa tersinggungan banget lo lupus tu. (W-1: 220225)

Menikmati ya gimana ya, ya menerima apa adanya gitu tho, kita misalnya punya sepeda motor ya kita manfaatkan sepeda motor untuk main, kemana, yang penting kan kita bahagia simple nya itu. (W-4: 235-237)

Berdasarkan informasi penelitian, informan mengatakan bahwa dirinya mengalami perbedaan sikap, aktivitas, dan cara berpikir dari sebelum kejadian NDE dan sesudah kejadian NDE. Informan menyatakan bahwa informan merasa lebih tenang, lebih bersyukur dan lebih mawas diri dalam menjalani kehidupan. Peneliti tidak menemukan perbedaan yang signifikan antara jenis kelamin, usia, jenis NDE dengan perubahan yang terjadi sebelum dan sesudah pengalaman NDE.

Makna Near-death experience adalah sebagai sebuah fase atau kejadian yang menyebabkan terjadinya perubahan secara sikap, aktivitas, dan pemikiran dalam kehidupan. Peneliti tidak menemukan hubungan antara pemaknaan NDE dengan usia ketika kejadian, jenis kelamin, maupun jenis NDE yang dialami informan. Seluruh informan menyatakan kejadian NDE sebagai kejadian yang telah merubah kehidupan dari pelakunya. Pernyataan ini sesuai dengan pengalaman NDE sering kali dihubungkan dengan perubahan positif yang berlangsung lama, khususnya, penurunan ketakutan dan kecemasan dan meningkatnya pengaruh positif (Greyson \& Stevenson, 1980; Groth-Marnat $\&$ Summers, 1998). Greyson menyertakan perubahan diri secara perilaku, cara berpikir dan aktivitas kehidupan dari pelaku NDE kejadian sebagai salah satu ciri-ciri dari kejadian NDE.

Selanjutnya, dalam NDE terdapat elemenelemen yang menyertai baik sebelum, sesudah dan saat kejadian NDE tersebut terjadi. Elemen-elemen tersebut yaitu kognitif, emosi, dan transendetal. Menurut Greyson (2000) elemen kognitif menyertakan pemfungsian yang luar biasa seperti perubahan persepsi waktu, kewaspadaan yang meningkat, pembangkitan ingatan yang cepat dalam bentuk kilas balik kehidupan, dan kemampuan kesadaran di samping perasaan terpisah dari badan. Penjelasan ini sesuai dengan hasil penelitian dimana informan menunjukan perilaku yang berbeda terhadap diri sendiri dan masyarakat. Informan menunjukan bahwa informan lebih waspada akan keadaan fisik dan mental informan. Elemen kognisi yang ditemukan pada penelitian ini berhubungan dengan kejadian sebelum pengalaman NDE terjadi. Kejadian 
tersebut dimaknai sebagai tanda-tanda akan datangnya peristiwa yang akan berpengaruh besar pada kehidupan. Elemen kognisi ini terlihat menonjol pada informan yang mengalami pengalaman NDE merasa dekat dengan kematian.

Elemen yang selanjutnya adalah elemen transendental. Greyson \& Stevenson (1980) menyatakan mengenai deskripsi NDE sebagai berikut; pengalaman NDE menyertakan perubahan ruang, waktu dan diri; perasaan damai dan euphoria; dan pertemuan dengan cahaya terang, tokoh religi, atau kerabat yang telah meninggal (Greyson \& Stevenson, 1980). Peneliti menyimpulkan bahwa elemen transendental terjadi ketika informan mengalami kejadian NDE yang menyertakan kejadian simbolis yang maknanya berbedabeda sesuai dengan kejadian dan interpretasi informan. Salah satu informan menceritakan kejadian NDE-nya disertai dengan menyaksikan dirinya berada di suatu padang pasir yang sangat luas dan matahari yang berada sangat dekat. Informan lain menceritakan saat kejadian NDE ia menyaksikan sendiri kejadian kecelakaan yang dialaminya lalu kemudian merasakan dirinya berada di suatu alam lain dengan padang rumput yang luas. Salah satu ciri dari NDE adalah bertemu dengan sesosok mahluk, tokoh religi, atau kerabat yang telah meninggal. Beberapa informan menunjukan ciri yang sama pada kejadian NDE nya.

Elemen yang selanjutnya adalah elemen emosi. Elemen emosional menyertakan intens akan rasa senang, bahagia, damai dan cinta tanpa syarat (Greyson, 2000). Peneliti menyimpulkan bahwa elemen ini merupakan efek sesudah kejadian NDE. Pada penelitian ini informan menunjukan bahwa kejadian NDE informan menyertakan perasaan lega dan perasaan lebih bisa menerima keadaan hidupnya. Informan juga menyatakan kejadian NDE telah membawa informan kepada keadaan dimana informan merasa lebih damai dalam menjalani kehidupan informan. Peneliti tidak menemukan ada perbedaan yang signifikan antara usia kejadian, jenis kelamin, jenis kejadian NDE yang dialami informan.

Informan merasakan perubahan dalam bersikap, aktivitas, dan cara berpikir dalam kehidupan informan. Informan merasa lebih tenang, lebih bersyukur, dan lebih mawas diri dalam menjalani kehidupan. Salah satu informan mengatakan kalau dirinya pasca kejadian NDE lebih berpikir kearah yang positif. Hal ini sejalan dengan pernyataan dari Matamua (2014). Pada khususnya, tiga karakteristik NDE - hilangnya rasa takut akan kematian, gejala sisa psikologis, dan kemampuan kesadaran kompleks - dapat memberikan wawasan dalam fenomenologi psikologis dari tahap awal kematian.

Tabel 1. Informan Penelitian

\begin{tabular}{|c|c|c|c|c|c|c|}
\hline No. & Nama & Jenis Kelamin & Usia & Pengalaman & $\begin{array}{c}\text { Usia } \\
\text { kejadian }\end{array}$ & Keterangan \\
\hline 1. & SR & Perempuan & 31 & Penyakit berisiko kematian, & 19 & $\begin{array}{l}\text { Penyakit lupus yang tidak bisa } \\
\text { disembuhkan }\end{array}$ \\
\hline 2. & $\mathrm{~B}$ & Laki-laki & 55 & Mati suri & 7,13 & Tiga kali meninggal dunia \\
\hline 3. & RAN & Laki-laki & 31 & Penyakit berisiko kematian & 14 & $\begin{array}{l}\text { Penyakit keturunan yang tidak } \\
\text { bisa disembuhkan, hanya bisa } \\
\text { dilakukan perawatan seumur } \\
\text { hidup }\end{array}$ \\
\hline 4. & $S$ & Laki-laki & 28 & Kecelakaan, koma & 21 & Kecelakaan, koma, dan amnesia \\
\hline 5. & SSBW & Laki-laki & 44 & Kecelakaan, out of body, koma & 25 & $\begin{array}{l}\text { Melihat dirinya sendiri yang } \\
\text { sedang kecelakaan }\end{array}$ \\
\hline 6. & RW & Laki-laki & 25 & Kecelakaan, out of body & 19 & $\begin{array}{l}\text { Melihat dirinya sendiri sedang } \\
\text { berjalan diatas gurun pasir }\end{array}$ \\
\hline
\end{tabular}




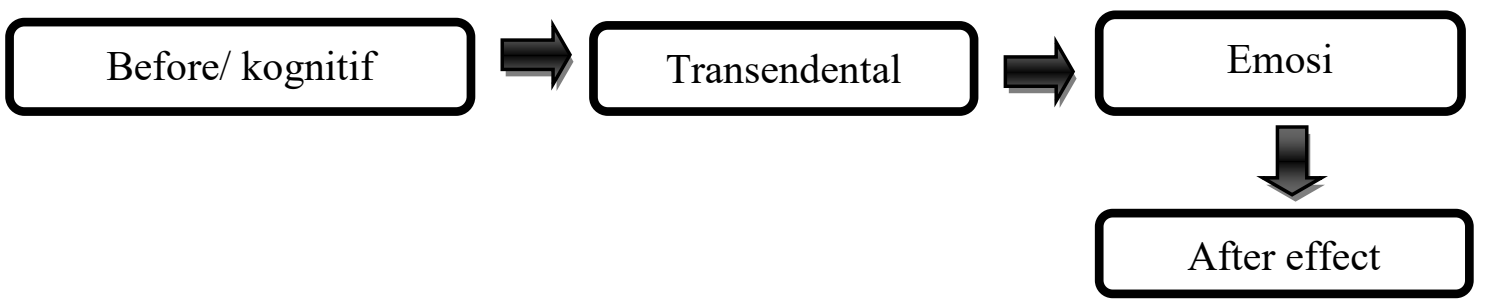

Gambar 1. Gambar Proses NDE

Proses NDE diawali dengan elemen kognitif yang terjadi pada saat kejadian berupa firasat yang dialami oleh individu seperti sering melamun, memikirkan orang terdekat. Individu kemudian mengalami elemen transendental yaitu kejadian simbolis seperti melihat diri sendiri, melihat cahaya, bertemu dengan kerabat yang telah meninggal. Proses yang selanjutnya adalah individu mengalami elemen emosi yaitu perasaan yang dirasakan oleh individu sesaat setelah mengalami NDE seperti rasa senang, lebih tenang dan cinta tanpa syarat. Proses yang selanjutnya adalah gejala sisa (after-effect) yaitu individu mengalami perubahan-perubahan sikap, dan pemikiran dalam menjalani kehidupannya.

Penelitian ini juga menyimpulkan bahwa Near-death experience adalah kejadian yang disertai elemen kogntif, elemen emosional, dan elemen transcendental dimana seseorang merasa mendekati kematian atau tidak dapat terhindar lagi dengan kematian namun karena suatu hal berhasil bertahan hidup lalu mengalami perubahan-perubahan dalam kehidupannya. Kejadian ini pada umumnya diawali dengan elemen kognisi sebagai penanda sebelum NDE terjadi berupa kejadian yang tidak biasa terjadi pada orang yang mengalaminya, kemudian terdapat elemen transendental yaitu kejadian simbolis seperti berada di suatu tempat, melihat cahaya, bertemu dengan keluarga yang telah meninggal, yang memiliki makna tertentu dan terjadi pada saat informan mengalami pengalaman NDE diikuti oleh elemen emosi yang merupakan efek sesudah (after-effect) dari kejadian NDE berupa perubahan pada sikap diri dan cara pandang terhadap kehidupan. Perbedaan yang paling besar terlihat adalah pada penyebab kejadian NDE yang dialami yaitu merasa dekat dengan kematian seperti kecelakaan atau kerusakan organ vital dan terjangkit penyakit parah. Pada informan yang terjangkit parah tidak menunjukan informasi yang signifikan terhadap elemen kognisi dan transendental. Sedangkan satu informan tidak dapat memberikan informasi mengenai elemen kognisi dan transendental karena mengalami hilang ingatan.

\section{SIMPULAN}

Kesimpulan penelitian mengenai dinamika psikologis elemen dekat dengan kematian (Neardeath experience) adalah sebagai berikut:

1. Makna NDE adalah sebagai kejadian mendekati kematian yang menyebabkan terjadinya perubahan secara sikap, aktivitas, dan pemikiran dalam kehidupan. Pada umumnya perubahan tersebut terjadi setelah kejadian NDE dan berlangsung pada waktu yang lama.

2. Hubungan antar elemen dalam kejadian NDE:

a. Elemen kognitif. Elemen kognitif merupakan kejadian-kejadian tidak biasa yang terjadi pada informan dan terjadi sebelum informan mengalami kejadian Near-death experience. Kejadian-kejadian tersebut dimaknai sebagai sebuah pertanda atau firasat terjadinya NDE.

b. Elemen transendetal. Elemen transendental adalah kejadian yang terjadi pada saat NDE pada informan. Pada penelitian ini elemen transendental yang terjadi berupa melihat diri sendiri (out of body), bermimpi bertemu kerabat yang telah meninggal, melihat sesosok mahluk, dan merasa berada di tempat 
lain. Kejadian pada elemen ini dimaknai sebagai kejadian simbolis yang memiliki makna tertentu sesuai dengan interpretasi pelaku.

c. Elemen emosi. Elemen emosi yang terjadi didalam penelitian ini adalah perasaan lega dan perasaan lebih bisa menerima keadaan hidup yang lebih baik dan mampu menerima perbedaan-perbedaan dari orang lain. Elemen ini memiliki efek sesudah (after-effect) kejadian NDE.

Dari uraian tersebut dapat disimpulkan bahwa pengalaman NDE diawali dengan elemen kognisi sebagai kejadian sebelum NDE, kemudian terdapat elemen transendental yaitu kejadian yang terjadi pada saat informan mengalami pengalaman NDE dan diikuti oleh elemen emosi berupa perasaan senang, ikhlas, dan mampu menerima serta memiliki efek sesudah (after-effect).
Peneliti menemukan bahwa penyebab NDE, yaitu kejadian merasa tidak terhindar kematian dan terjangkit penyakit parah memiliki berbedaan yang signifikan atas elemen kognisi dan elemen transendental. Informan dengan kejadian NDE merasa tidak terhindar dari kematian menyatakan bahwa informan mengalami kejadian-kejadian yang berhubungan dengan elemen kognisi dan elemen transendental. Informan dengan kejadian NDE terjangkit penyakit mematikan tidak memberikan banyak informasi mengenai kejadian-kejadian yang berhubungan dengan elemen kognisi dan elemen transendetal. Terdapat informan yang menyatakan tidak terlalu bisa merasakan kejadian sebelum NDE dan beberapa minggu setelah NDE karena informan mengalami koma dan hilang ingatan setelah kejadian NDE. Satu informan menyatakan bahwa informan tidak terlalu ingat dengan kejadian NDE yang di alaminya karena usia informan yang masih kecil ketika NDE terjadi.

\section{DAFTAR PUSTAKA}

Atwater, P. M. H. (2008). Coming back to life. Examining the after-effects of the near-death experience (2nd rev. ed.). Kill Devil Hills, NC: Transpersonal Publishing.

Greyson, B, \& Stevenson, I. (1980). The phenomenology of near-death experiences. American Journal of Psychiatry Association

Greyson, B. (1998) Defining Near-death experiences, Mortality, Vol.4, No. 1, 1999, University of Virginia, United States

Greyson, B. (2000). Near-death experiences. Varieties of Anomalous Experience: Examining the Scientific Evidence, Washington, DC

Hidayat, K, (2012). Psikologi Kematian: Mengubah Ketakutan MenjadiOptimisme. Noura Books (PT. Mizan Publika)

Ketis, Z-K. (2011). Life Changes in Patients After Out-of-Hospital Cardiac Arrest: The Effect of Neardeath experiences, Springer Science \& BusinessMedia B.V.

Lommel, P. V., Wees, R.D., Meyers, V., \& Elfferi (2001)ch, I. Near-death experience in survivors of cardiac arrest: a prospective study in the Netherlands. The Lancet. Volume 358, P2039-2045, December 15, 2001

Lommel, P. V. (2006) Near-death experience, Consciousness, and the Brain A New Concept About The Continuity of Our Consciousness Based on Recent Scientific Research on Near-death experience In Survivors of Cardiac Arrest. World Futures, 62: 134-151

Matamua, Natasha A. Tassell (2014). Near-death experiences and the Psychology of Death, Massey University, New Zealand OMEGA, Vol. 68 
Moody, R. A. (1975). Life after life. Covington, GA: Mockingbird Books.

Moody, R.A \& Perry, P. (1988). The Light Beyond. New York: Bantam

Moody, R.A. (1977). Reflections on life after life. St Simon's Island, GA: Mockingbird Books

Noyes, R., Fenwick, P., Holden, J. M., \& Christian, S. R. (2009). After effect of pleasurable Western adult near-death experiences. In J.M. Holden, B. Greyson, \& d. James (Eds.), The handbook of near-death experiences. Praeger Publishers 